\title{
Proximate and Selected Mineral Elements Analysis of Nigerian Ziziphus spina-christi (L.) Willd Edible Fruit Pulp
}

\section{Yelwa Sani Abubakar}

Department of Pure and Applied Chemistry, Usmanu Danfodiyo University Sokoto, Sokoto State, Nigeria; e-mail: abubakar.sani1@udusok.edu.ng; Phone No.: +2347036154525

\begin{abstract}
Ziziphus spina found in the tropical regions of the world is a small tree capable of resisting heat and drought. The edible portion of the fruit is widely preserved as feed for human and animal especially in drought and famine ravaged nations of the world. The edible fruit of Z. spina were procured from a local market in Gusau, Zanfara State NorthWestern Nigeria in October 2019. They were prepared for proximate and mineral analyses using standard analytical methods. The results showed the percentage (\%) moisture, ash, crude lipid, crude protein, crude fibre and total carbohydrate contentas3.13, 15.22, 3.11, 11.12, 6.45 and 64.10 respectively while the calorific values was reported to be $328.87 \mathrm{kcal} / 100 \mathrm{~g}$. The elemental analyses revealed that potassium and copper were the most and least abundant element with concentrations of 256.12 and 2.37 $\mathrm{mg} / 100 \mathrm{~g}$ dry weight respectively. The findings from this study reveal that Z.spina fruit contains important mineral elements that would possibly improve on the proper metabolic activity and therefore could improve on the health standard if properly utilized.
\end{abstract}

\section{Introduction}

In Nigeria, wild fruits are commonly both rural and urban dwellers especially during dry season when most cultivated fruits are available [1]. Wild and semi wild food are frequently consumed in rural communities alternative sources of essential nutrient body [2].Malnutrition refers to deficiencies, excesses or imbalances in a person's intake of energy and/or nutrients. The disease condition has constituted a serious global health problem in developing countries and it's more pronounced among pregnant women and

Received: November 6, 2020; Accepted: December 26, 2020

Keywords and phrases: fruit, mineral, proximate, Ziziphus spina.

Copyright () 2021 Yelwa Sani Abubakar. This is an open access article distributed under the Creative Commons Attribution License, which permits unrestricted use, distribution, and reproduction in any medium, provided the original work is properly cited. 
children of the rural populace. Plants are richly packed with life-enhancing nutrients such as protein, iron, fibre, vitamins and omega-3 fatty acids that can help the body fight diseases and promote good healthy living [3].

The increasing population of many tropical countries like Nigeria has led to the awareness of the importance of some plants as valuable source of nutrients to man especially in rural areas where they contribute substantially to protein, mineral, vitamins, fiber and other nutrients usually in short supply in their daily diets [4-6]. Wild plants are commonly being consumed by both rural and urban dwellers to serve as alternative sources of essential nutrient required by the body [1]. Mineral elements though required in small portion of the total body weight; they are nevertheless of great physiological importance particularly in body metabolism where they play vital roles in the general wellbeing as well as in the cure of diseases [7-8].

Ziziphus is a genus of about 40 species of spiny shrubs and small trees in the buckthorn family, Rhamnaceae, distributed in the warm temperate and subtropical region throughout the world. The leaves are alternate, entire, with three prominent basal veins, and 2-7 cm long; some species are deciduous, others evergreen. The flowers are small, inconspicuous yellow-green. The fruit (Figure 2) is an edible drupe, yellow-brown, red, or black, globose or oblong, 1-5 cm long, often very sweet and sugary, reminiscent of a date in texture and flavor [9]. The plant is locally known as "Magarya" in Hausa is a multipurpose tree species belonging to the family Rhamnaceae. It is an important cultivated tree and one of the few truly native tree species of Arabia that is still growing along with many newly introduced exotic plants [10]. The study sought to determine the phytoconstituents, nutritional status and antimicrobial activity of the methanol extract of the leaves of Z. spina collected from Gusau central market, Zamfara State Nigeria. The present study was aimed at investigating the proximate, mineral and anti-nutritive compositions of the leaves of Cassia siamea and whole plant of Plantago rugelii cultivated in Owerri, Imo state and Ibadan, Oyo state respectively in order to evaluate their health benefits. 


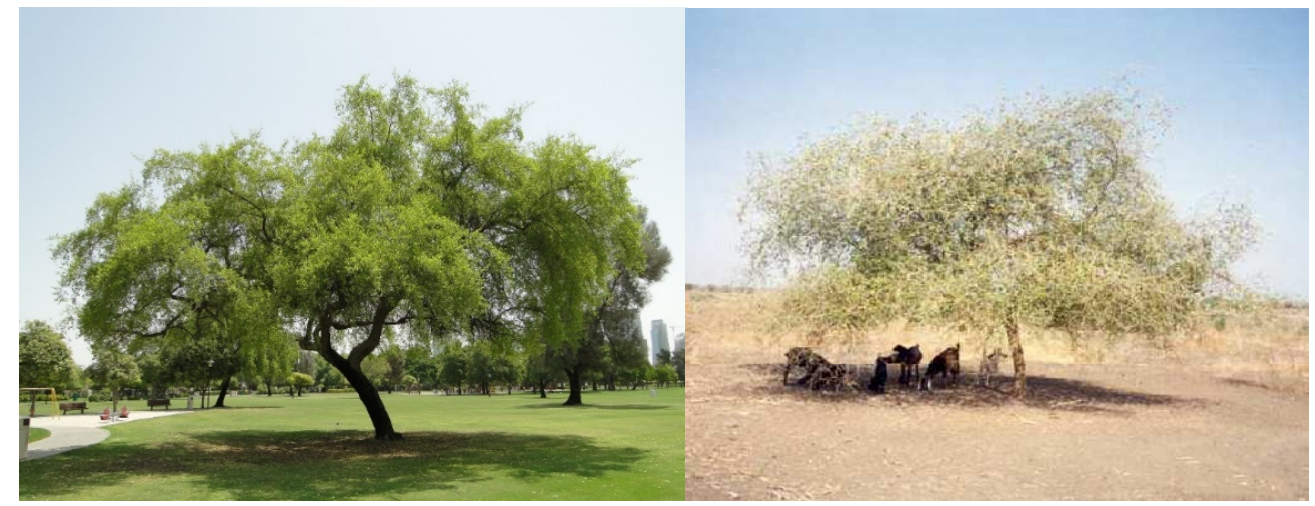

(a)

(b)

Figure 1. Ziziphus spina tree in its natural habitat during the (a) rainy and (b) dry seasons.

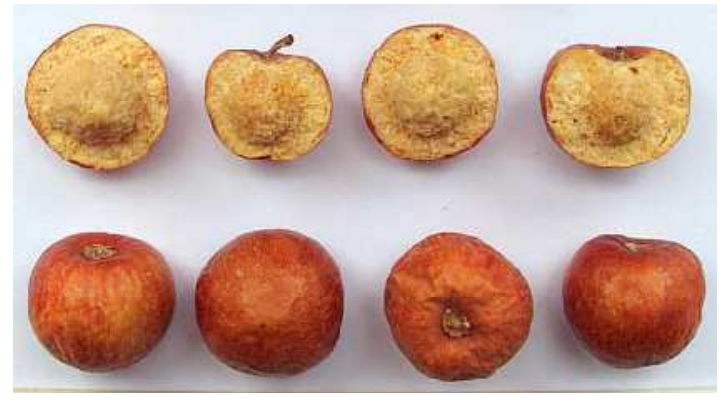

Figure 2. Ziziphus spina whole fruits and cut fruits revealing its seed.

\section{Materials and Methods}

\section{Sample Collection, Authentication and Preparation}

Dried fruits of Z. spina were procured from Gusau central market in October, 2019. They were immediately transported to the central laboratory of the Department of Pure and Applied Chemistry, Usmanu Danfodiyo University Sokoto, Sokoto State Nigeria. They were identified and authenticated by Mallam Abdulaziz Sani of the Botany Unit, Department of Biological Sciences, Usmanu Danfodiyo University Sokoto where herbarium specimen was deposited for future reference. The samples were washed with running tap water to remove dust and earthy impurities. The fruits were reduced to fine powder using a clean grinding machine to achieve a smooth flour, sieved using a clean sieve to make a fine powder. The powder were preserved in a glass airtight glass container and preserved at room temperature until ready to use. 


\section{Proximate analyses}

Moisture content was determined at $105^{\circ} \mathrm{C}$. Ash content was determined at $550^{\circ} \mathrm{C}$. Crude protein, lipid and fibre were also determined according to the procedures of AOAC, [11]. The nitrogen content was determined by the Kjeldhal procedure; the total carbohydrate was determined by simple difference as follows: Carbohydrate $=100-$ $(\%$ Ash $+\%$ Crude protein $+\%$ Crude fat $+\%$ Crude fibre $)$. The calorific value was obtained by the summation after multiplying percentage carbohydrate, protein and fat by factors of 4, 4 and 9 respectively and expressed in Kcal/100g [2]. All analyses were carried out in triplicates.

\section{Mineral analyses}

$2 \mathrm{~g}$ of the dried sample was digested with $24 \mathrm{~cm}^{3}$ mixture of nitric acid /perchloric acid in the ratio 12:4. The minerals $\mathrm{Ca}, \mathrm{Mg}, \mathrm{Fe}, \mathrm{Cu}$ and $\mathrm{Zn}$ were determined using atomic absorption spectrophotometry, $\mathrm{Na}$ and $\mathrm{K}$ using atomic emission spectrometry [11], while phosphorus was determined by the molybdenum blue colorimetric method [12].

\section{Statistical analysis}

All data obtained from the analysis were performed in triplicate and expressed as mean \pm standard deviation.

\section{Results and Discussion}

\section{Proximate analysis}

The proximate compositions of $Z$. spina fruits are shown in Table 1.

Table 1. Proximate composition of $Z$. spina fruit

\begin{tabular}{cc}
\hline Parameters & $\boldsymbol{\%} \pm$ SD \\
\hline Moisture & $3.13 \pm 0.67$ \\
Crude Ash & $15.22 \pm 0.22$ \\
Crude Lipid & $3.11 \pm 0.18$ \\
Crude Fibre & $6.45 \pm 0.28$ \\
Crude Protein & $11.12 \pm 0.11$ \\
Available CHO & $64.10 \pm 0.17$ \\
Calorific Value (KJ/100g) & $328.87 \pm 7.11$ \\
\hline
\end{tabular}

Key $: \mathrm{CHO}=$ Carbohydrate, $\mathrm{KJ}=$ Kilojoules, $\mathrm{SD}=$ Standard deviation for triplicate determination 
Moisture content in plants assists in maintaining the protoplasmic contents of cells but make herbs perishable and susceptible to microbial degradation during storage [13]. The result of the moisture content for the plant fruit fall far below the $12 \%$ set by Africa Pharmacopoeia hence suggests that the fruit will not be prone to microbial attack and hence would have a long shelf life. This explains why the fruit are preserved for a long time especially during famine and drought conditions. The crude ash value indicates the level of mineral elements content preserved in a plant and it was recommended that plants with ash content above $8.8 \%$ are useful health wise [14]. The crude ash value of $15.22 \%$ for the powdered drug of Z. spina indicates that the fruits is rich in mineral elements that may be nourishing and suitable for consumption since high mineral elements in foods enhances growth and development as well as catalyses metabolic processes in human body [15]. The low fat content of 3.11\% suggests that the fruit could be recommended as part of weight reducing diet, since low fat food reduces the level of cholesterol and obesity $[16,17]$. The result of the fibre content shows that the fruit of the plant has the capability of lowering blood cholesterol levels as well as reduce the risk of various cancers [15]. There has been recommendation for keeping fibre intake low in the nutrition of infants and weaning children because high fibre levels could lead to gut mucosa irritation mucosa [18] as well as gut perturbation in the young of piglets and chickens [19].The fruit had an appreciable amount of protein which could be explored as either an alternative or complementary source of protein considering the level of protein deficiency in the society in general and rural populace in particular. The result of the available carbohydrate showed that both samples have a high amount of carbohydrate. This shows that the fruits of $Z$. spina could be considered as a potential source of carbohydrate since it compares well to cereals which possesses around $72-90 \%$ carbohydrate content [20]. This explains why the fruit is a good source of immediate energy for both human and animals as reflected in their high calorific value over 300 kilojoules per $100 \mathrm{~g}$ of sample consumed. This explains why the fruit boost the energy of its consumers for the supply of instant energy especially during drought and famine conditions [21]. 


\section{Mineral analysis}

The result for the mineral composition of the fruit of $Z$. spina is shown in Table 2 .

Table 2. Mineral analysis of $Z$. spina fruit.

\begin{tabular}{cc}
\hline Minerals & $\mathbf{m g} / \mathbf{1 0 0} \mathbf{g} \mathbf{D W} \pm \mathbf{S D}$ \\
\hline Potassium & $256.12 \pm 0.67$ \\
Sodium & $91.60 \pm 0.22$ \\
Calcium & $3.37 \pm 0.18$ \\
Phosphorus & $3.13 \pm 0.11$ \\
Magnesium & $5.99 \pm 0.28$ \\
Copper & $2.37 \pm 0.17$ \\
Zinc & $9.25 \pm 0.11$ \\
Iron & $37.12 \pm 0.17$ \\
\hline
\end{tabular}

Key $:$ DW $=$ Dry weight, $\mathrm{SD}=$ Standard deviation for triplicate determination, $\mathrm{ppm}=$ parts per million

The values of sodium $(91.60 \mathrm{mg} / 100 \mathrm{~g})$ and potassium $(256.12 \mathrm{mg} / 100 \mathrm{~g})$ was reported for the edible fruit of $Z$. spina. According to IMFNB, [22], a healthy adult should eat less than 2400 and $3500 \mathrm{mg}$ of sodium and potassium per day to reduce the risk of elevated blood pressure which predisposes one to coronary heart diseases, stroke, congested heart failure and kidney diseases as well control hypertension respectively [23]. The reported value of the sample in terms of sodium content falls far below this value hence could be regarded as being heart friendly although sodium has been reported to regulate fluid balance in the body and helps in the proper functioning of muscles and nerves [24]. The results reported for the sodium and potassium contents showed that the fruits could help to reduce high blood pressure in hypertensive patients hence hold promise for preventing hypertension as well as lower blood pressure in hypertensive patients. Calcium is an important constituent of bones which helps the body to contract properly, blood to clot easily as well as nerves to convey messages correctly as well as essential for disease prevention and control [25]. Thou the concentration of calcium in the edible is low $(3.37 \mathrm{mg} / 100 \mathrm{~g})$, it could however thou contribute to the nutritional significance of the body in terms of calcium consumption. The relatively low value of 
phosphorus $(3.13 \mathrm{mg} / 100 \mathrm{~g})$ collaborates with calcium as it is required by children, lactating women for bones and teeth development [26]. The low concentration of calcium and phosphorus reported in this study showed that the fruit might not support the formation of bones in the body especially during starvation periods. Magnesium helps in regulating blood pressure hence play a role in preventing/managing sudden cardiac arrest and ischemia as well as help in relaxing muscles along the airway to the lungs thus, allowing asthma patients to breathe easier [27]. It also plays a supportive role to calcium in terms of the structural development of bones [28]. The $5.99 \mathrm{mg} / 100 \mathrm{~g}$ reported value of magnesium fall short of the daily recommended value of $400 \mathrm{mg}$ for adults and children aged 4 and above [27]. The copper content of $2.37 \mathrm{mg} / 100 \mathrm{gdry}$ weight was found to be within the recommended daily allowance of $1.5-3.0 \mathrm{mg}$ per day for adults. The fruits of $Z$. spina could therefore be recommended as a good source of copper. Copper helps the body to use iron and sugar properly. It is also necessary for bone growth and nerve function. Deficiency of copper may result to anaemia, osteoporosis (weak bones) and bone and nervous systems [29]. Zinc is an essential trace element for protein and nucleic acid synthesis. It is vital for normal body development especially in periods of rapid growth such as in infancy, adolescence and during recovery from illness [30]. The result of this analysis shows that the concentration of zinc in both samples to be $9.25 \mathrm{mg} / 100 \mathrm{~g}$ dry weight. Zinc also helps in carbohydrate and protein metabolism, assists in the metabolism of vitamin A from its storage site in the liver as well as facilitates the synthesis of DNA and RNA necessary for cell production [27]. Iron content of $37.12 \mathrm{mg} / 100 \mathrm{~g}$ dry weight was reported for the edible fruit of the plant. Iron helps in the formation of blood and in the transfer of oxygen and carbon (IV) oxide from one tissue to another as well as constitutes an important element in the diet of pregnant women, nursing mothers, infants convulsing patients and to the elderly in preventing anaemia and other related diseases [31].

\section{Conclusion}

It can be concluded that the fruits of $Z$. spina is a good source of important minerals to animal and human through dieting. The findings from this research agreed favorably with those of other wild plants recommended as food supplement in literature. The information obtained from this analysis would therefore serve as a guide for the possible utilization of Z. spina edible fruit pulp by animal feed manufacturers, public health authorities, and other food regulatory bodies. 


\section{References}

[1] S. Muhammad, K.J. Umar, N.A. Sani and S. Muhammad, Evaluation of nutritional and antinutritional profile of ginger bread plum (Neocarya macrophtlla) seed kernel, Int. J. Sci. Technol. 4 (2015), 361 -367.

[2] L.G. Hassan, A.M. Sokoto, M.A. Ngaski, S.A. Anka, B.M. Chanchangi and C. Ogbiko, Nutritional and antinutritional analyses of Hura crepitans seeds cultivated in Sokoto North L.G.A, North-Western Nigeria, Bayero Journal of Pure and Applied Sciences 11(1) (2018), 126-130. https://doi.org/10.4314/bajopas.v11i1.22.

[3] H.N. Ogungbenle and Y.F. Anisulowo, Evaluation of chemical and fatty acid constituents of flour and oil of walnut (Juglans regia) seeds, British Journal of Research 1(3) (2014), 113-119.

[4] B.N. Enemchukhu, N. Uchenna, S.C. Udedi and X.C. Akalonu, Nutritional and antinutritional evaluation and phytochemical composition of aqueous leaf of Mucuna pruriens, Bioscientist J. 3(1) (2015), 93-100.

[5] J.O. Odedeji, G.O. Oyeleke, L.A. Ayinde and L.A. Azeez, Nutritional, antinutritional compositions and organoleptic analyses of raw and blanched cocoyam (Colocasia esculenta) leaves, J. Env. Sci. Toxicol. Food Tech. 8(2) (2014), 45-48. https://doi.org/10.9790/2402-08224548

[6] L.G. Hassan, A.H. Onwuasoanya, S.C. Onwuasoanya, S.I. Kolawole and C. Ogbiko, Nutritional composition, physicochemical and functional properties of peeled and unpeeled Dennettia tripetala (pepper fruit), Global Scientific Journals7(4) (2019), 332349 .

[7] E.J. Underwood, Trace Elements in Human and Animal Nutrition, 3rd ed., Academic Press, New York, 1977, pp. 143-147.

[8] A.S. Prasad, Essential and Toxic Elements in Human Health and Disease: An Update, Wiley-Liss, New York, 1993, pp. 232-239.

[9] B. Adzu, S. Amos, C. Wambebe and K. Gamaniel, Antinociceptive activity of Zizyhpus spina-christi root back extract, Fitoterapia 72 (2001), 344-350. https://doi.org/10.1016/S0367-326X(00)00289-6

[10] J.N. Keta, Proximate and mineral elements analysis of Ziziphus mauritiana fruits, UMYU Journal of Microbiology Research 2(1) (2017), 247-250.

[11] AOAC, Official methods of analysis (15th ed.), Washington D.C USA, Association of Official Analytical Chemists, Wilson Boalevard, Arlinton Virginia USA 2 (1990), 910928. 
[12] C.A. James, Analytical Chemistry of Food, Chapman and Hill, London, 1995, pp. 21-32.

[13] P.M. George, Encyclopedia of Food, Vol. 1, Humane Press, Washington, 2001, pp. 526.

[14] B.S. Antia, E.J. Akpan, P.A. Okon and I.U. Umoren, Nutritive and anti-nutritive evaluation of sweet potatoes (Ipomoea batatas) leaves, Pak. J. Nutr. 5 (2006), 166-168. https://doi.org/10.3923/pjn.2006.166.168

[15] A. Muhammad, S.M. Dangoggo, A.I. Tsafe, A.U. Itodo, and F.A. Atiku, Proximate, minerals and anti-nutritional factors of Gardenia aqualla fruit pulp, Pak. J. Nutr. 10(6) (2011), 577-581. https://doi.org/10.3923/pjn.2011.577.581

[16] M.N. Gordon and M. Kessel, Perspective in Nutrition, McGraw Hill Company, Ohio, New York, 5th ed., 2002, 257-281.

[17] L.G. Hassan, S.M. Dangoggo, K.J. Umar, I. Saidu and F.A. Folorunsho, Proximate, minerals and anti-nutritional factors of Daniellia oliveri seed kernel, Chem Class J. 5 (2008), 31-36.

[18] M.O. Bello, O.S. Farade, S.R.A. Adewusi, and N.O. Olawore, Studies of some lesser known Nigerian fruits, Afr. J. Biotechnol. 7 (2008), 3972-3979.

[19] I.C. Eromosele, C.O. Eromosele and D.M. Kuzhkuzha, Evaluation of mineral elements and ascorbic acid contents in fruits of some wild plants, Plant Food. Hum. Nutr. 41 (1991), 151-154. https://doi.org/10.1007/BF02194083

[20] S.R.A. Adewusi, J. Udio and B.A. Osuntogun, Studies on the carbohydrate content of breadfruit (Artocarpus communis Forst) from South-Western Nigeria, Starch Nutr. 47 (1995), 289-294. https://doi.org/10.1002/star.19950470802

[21] S.S. Amina, G. Jens, H. Karl and B. Andreas, Ziziphus spina-christi (L.) Willd.: a multipurpose fruit tree, Genet. Resour. Crop Evol. 55 (2008), 929-937. https://doi.org/10.1007/s10722-007-9299-1

[22] IMFNB, Dietary Reference Intake: Calcium, Phosphorus, Magnesium, Vitamin D and Fluoride. Institute of Medicine, Food and Nutrition Board, Washington DC, National Academy Press, 1997, pp 213-216.

[23] V. Arinathan, V.R. Mohan and A.J. De Britto, Chemical composition of certain tribal pulses in South India, International Journal of Food Sciences and Nutrition 54 (2003), 209-217. https://doi.org/10.1080/09637480120092026

[24] W.J.A. Payne, An Introduction to Animal Husbandry in the Tropics, Longman Publishers, Singapore, 1990, pp. 92-110.

[25] A.B. Aliyu, A.M. Musa, and J.A. Oshaniyi, Phytochemical analysis and mineral 
composition analysis of some medicinal plants of Northern Nigeria, Nigerian Journal of Pharmaceutical Sciences 7(1) (2008), 119-124.

[26] L. Margaret, and B. Vickery, Plant Products of Tropical Africa, Macmillan in College ed. London, 1997, pp. 45-53.

[27] C. Ogbiko, Phytochemical, proximate, mineral and anti-nutritional compositions of Cassia siamea (Fabaceae) leaves and whole plant of Plantago rugelii (Plantaginaceae), FUNAI Journal of Science and Technology 4(1) (2020), 07-22.

[28] A.G. Jacob, D. Etong and A. Tijjani, Proximate, mineral and anti-nutritional compositions of melon (Citrullus lanatus) seeds, British Journal of Research 2(5) (2015), $142-151$.

[29] G.W. Mielcarz, A.N. Howard, N.R. Williams, G.D. Kinsman, E. Moriguchi, Y. Moriguchi, S. Mizushima and Y. Yamori, Copper and Zinc status as a risk factor for ischemic heart disease: A comparison between Japanese in Brazil and Okinawa, J. Trace Elem. Exp. Med. 10 (1997), 29-35.

[30] G. Melaku, Development of molecular marker for pro vitamin A Carotenoid (pVAC) genes in cassava, Abstract submitted to ISTRC-AB 11th symposium, Kinshasa, (2005), 21.

[31] E.A. Oluyemi, A.A. Akilua, A.A. Adenuya and M.B. Adebayo, Mineral contents of some commonly consumed Nigerian foods, Sci. Focus 11 (2006), 153-157. 